Uniwersytet im. Adama Mickiewicza w Poznaniu

Wydział Neofilologii

Instytut Filologii Rosyjskiej i Ukraińskiej

Иркутский государственный университет

Институт филологии, иностранных языков и медиакоммуникации

кафедра русского языка и общего языкознания)

tel.: + 4857679825

e-mail: ekasta@amu.edu.pl

ORCID ID: https://orcid.org/0000-0001-6323-2376

\title{
Ku wstępnej typologii ironicznych wyrazów metajęzykowych (na podstawie języka rosyjskiego i polskiego)
}

Słowa kluczowe: ironia werbalna, język polski, język rosyjski, wyrazy metajęzykowe

\section{Uwagi wstępne}

W artykule chciałabym przyjrzeć się jednostkom metajęzykowym, które, będąc użyte w składzie tekstu jako komentarz do innej wypowiedzi (tekstu, wyrazu, maniery wypowiadania się etc.), nadają jednocześnie całemu temu tekstowi lub jego fragmenowi wymiar ironiczny czy też - inaczej świadczą o ironicznej intencji autora. Efekt ironiczny pojawia się w wyniku semantycznego oraz pragmatycznego dostosowania się do siebie komponentów znaczeniowych wyrazu metajęzykowego i komentowanej wypowiedzi, przy czym dodatkowej, zgodnej z kontekstem interpretacji wymaga właśnie ten pierwszy, więc jest jednocześnie nośnikiem ironii i jej sygnałem. Zarówno same ironiczne wyrazy metatekstowe, ich właściwości strukturalne oraz semantyczne, jak i relacje poszczególnych wyrazów z fragmentami tekstu przez nie komentowanymi mogą wyglądać bardzo różnie, zatem niezbędne wydaje się wyodrębnienie kryteriów, które umożliwią wypracowanie typologii opisywanych jednostek. 
Krótkiego wyjaśnienia wymagają kwestie terminologiczne (wiążące się z problemami metodologicznymi). Używam terminu metajezykowy zgodnie z klasycznym ujęciem funkcji metajęzykowej przez Romana Jakobsona [Jakobson 1960, 438], czyli we wszystkich tych przypadkach, gdy mowa jest nie o rzeczywistości pozajęzykowej, lecz o samym języku. W polskiej tradycji lingwistycznej w tym znaczeniu używa się głównie terminu metatekst (i innych przez niego motywowanych $)^{1}$, w pracach anglojęzycznych pojawia się określenie reflexivity [Lucy 1999], ale biorąc pod uwagę wielość i odmienność tworów lingwistycznych, których może dotyczyć komentarz nadawcy (może to być struktura własnej wypowiedzi, wypowiedzenie bohatera powieści, odrębny leksem czy językowe osobliwości pewnej epoki), zostanę przy szerszym pojęciu metajęzyka i wyrazów metajęzykowych.

Ironia $\mathrm{z}$ kolei znajduje się $\mathrm{w}$ kręgu tych wspólnych dla nauk humanistycznych terminów, których desygnatów nie sposób wymienić w ramach jednego artykułu, nawet jeśli ów artykuł będzie zawierał samo wyliczenie tradycji użycia tej jednostki w językoznawstwie, retoryce, historii i teorii literatury czy psychologii w różnych okresach funkcjonowania tych dyscyplin itd. Jest rzeczą oczywistą, iż klasyczne podejście do ironii jako do tropu, którego mechanizm polega na tym, że „ukryty sens jest przeciwny czy prawie przeciwny sensowi jawnemu" [Gray 1960, 220], nie obejmuje wszystkich (a nawet większości) przypadków zastosowania ironii w tekście literackim czy mowie potocznej. Pomijając w tym miejscu dyskusję o zakresie omawianego pojęcia, zaznaczę tylko, że ironię, za Rogerem Kreuzem oraz Kristenem Linkiem, traktuję tutaj jako zjawisko, które polega na wyrażaniu poglądów, sądów, ocen niezgodnych z rzeczywistą intencją nadawcy oraz szeroko rozumianym kontekstem [Kreuz, Link 2002, 127], czemu towarzyszy (przynajmniej w zamierzeniu) efekt komiczny.

\section{Ironiczne wyrazy metajęzykowe: funkcja i struktura}

Metajęzykowe wykładniki ironii więc, najogólniej rzecz ujmując, funkcjonują jako komentarz do innej wypowiedzi, ujawniający stosunek (zazwyczaj negatywny) osoby komentującej do formy oraz treści wypowiedzi komentowanej, do wypowiadającej się osoby oraz, last but not least,

1 Zob. m.in. [Wierzbicka 1971]; [Ożóg 1990]; [Charciarek 2010] i inne. Dorota Piekarczyk natomiast konsekwentnie rozróżnia desygnaty terminów metajęzyk i metatekst, zob. [Piekarczyk 2012]. 
jej poglądów i wyborów. Wydaje się, że jednostki metajęzykowe są tworzywem bardzo wygodnym, w wyższym stopniu wdzięcznym, jeśli chodzi zarówno o konstruowanie wypowiedzi ironicznej, jak i o dekonstruowanie ironii przez odbiorcę czy też badacza. Uzasadnienie naturalnego związku pomiędzy metajęzykowymi właściwościami języka oraz ironią dosyć szczegółowo przedstawiłam we wcześniejszej pracy [Starodworskaja 2020]; tutaj więc tylko w dużym skrócie zaznaczę logikę takiego rozumowania: ironia zawsze wiąże się $\mathrm{z}$ wartościowaniem (na tym m.in. polega jedna z głównych różnic pomiędzy ironią a humorem według Salwatore Attardo [Attardo 2002]) $\Rightarrow$ to, co się ocenia, powinno posiadać formę materialną oraz wartość semiotyczną; ocena dotyczy przede wszystkim świadomości, poglądów, sądów, które uzewnętrzniają się $\mathrm{w}$ wypowiedziach $\Rightarrow$ nie ma nic dziwnego w tym, że wiele komentarzy metajęzykowych zawiera ładunek ironiczny.

Mamy więc do czynienia, jak już zaznaczyłam wyżej, z bezpośrednią reakcją nadawcy na czyjąś wypowiedź (w tym własną), jej formę, treść, warunki jej powstania etc., przy czym ironiczną sensu stricto będzie właśnie ta reakcja, (por. pogrubione fragmenty w przykładach poniżej, podkreślone natomiast zostały elementy kontekstu ważne dla interpretacji, przede wszystkim fragmenty mowy niezależnej):

(1) Глава «Декки» Дик Роу тогда пророчески заявил: «Гитарные группы уже выходят из моды, мистер Эпстайн» (Антология. The Beatles, пер. У.В. Сапциной).

(2) Łupko wyciągnął z kieszeni blok i ołówek.

- Co mistrz sądzi o pięknie?

Odpowiedziałem bez namysłu:

- Wierze w świetlana przyszłość piękna.

- Cudownie! Cudownie! - szeptał Łupko, zapisując rewelacyjną moją odpowiedź (J. Tuwim, Wywiad).

Warto zwrócić uwagę na to, iż analizowane tutaj przykłady pochodzą ze źródeł w wyższym stopniu różnorodnych, reprezentujących rozmaite odmiany języka (są to teksty literackie fikcyjne oraz non-fiction, medialne, potoczne). Wydaje się jednak, że wspomniana różnorodność nie wyklucza zastosowania tych samych narzędzi badawczych, ponieważ struktura analizowanego fragmentu tekstu zazwyczaj się powtarza (czyjaś wypowiedź, często bohatera + komentarz do niej narratora/autora). Są niewątpliwie różnice, które zostaną uwzględnione w typologii ironicznych wyrazów metajęzykowych, lecz podobieństw jest więcej, co zresztą uprawnia nas do rozpracowania tejże typologii. 


\section{Kryteria typologizacji metajęzykowych wykładników ironii}

Trzeba zaznaczyć, że jest to zaledwie wstęp do opisu najrozmaitszych ironicznych wyrazów metajęzykowych oraz ich relacji z wypowiedzią komentowaną, próba ustalenia czynników określających funkcjonowanie tych jednostek, a więc bardzo możliwe, iż odkrycie nowych przykładów w znacznym stopniu wpłynie na zmianę systemu kryteriów, które bierzemy tutaj pod uwagę. Warto oprócz tego dodać, że bardzo rzadko mamy do czynienia ze ścisłą dychotomią czy trychotomią - prawie zawsze (szczególnie w przypadku określenia typu sprzeczności) jest to kontinuum, czyli konkretny przykład może posiadać cechy różnych typów, chociaż są też przypadki „czyste”. Wymieńmy więc podstawowe kryteria, według których będziemy porządkować cały ogrom ironicznych jednostek metajęzykowych:

\subsection{Status nadawcy charakterystyki metajęzykowej}

Rozróżnienie pomiędzy autorem (a) i narratorem (b) szczególnie ważne jest w przypadku literackich tekstów fikcyjnych [Hühn et al. 2009, 2] (w tekstach non-fiction komentarz metajęzykowy prawie zawsze należy do autora tożsamego w tym przypadku z narratorem). Wynika z niego m.in. ustalenie celu ironii, mianowicie podmiotu komunikacyjnego, którego dotyczy ironiczny komentarz metajęzykowy; w pierwszym przypadku będzie to bohater, w drugim narrator - tak jak w przytoczonych powyżej przykładach (1) i (2): charakterystyka пророчески заявил należy do autora i dotyczy osoby trzeciej, o której jest mowa, mianowicie zdolności (jak się okazuje, słabych) Dicka Rowe'a do przewidywania przyszłości, natomiast określenie rewelacyjna moja odpowiedź jest fragmentem wypowiedzi narratora, od której odcina się rzeczywisty autor (Tuwim przecież nie może się utożsamić z wysoce pozytywną oceną kliszy językowej, a więc mamy tu do czynienia z przypadkiem narratora niegodnego zaufania [Padučeva 1996, 216], o czym jeszcze będzie mowa). Przytoczmy jeszcze dwa przykłady, z których w pierwszym komentarz metajęzykowy należy do narratora, więc właśnie narrator jest celem ironii, autor natomiast tylko pozornie zgadza się z charakterystyką wypowiedzi nadanej przez narratora:

(3) Nie zapomnij o bąmocie: „Bardzo mi przynajmniej” (zamiast przyjemnie). Dobre powiedzonko i swoje zawsze robi (J. Tuwim, Wskazówki dla dowcipnisiów),

w kolejnym zaś komentarz należy do podmiotu komunikacyjnego, w którym zbiegają się postacie autora oraz narratora, a celem ironii jest bohaterka, mianowicie jej sposób udzielania się w dyskusjach: 
(4) - Ну нет, мисс Оливер, дорогая, вы сами знаете, что это необоснованное утверждение. Вы знаете, что мы ровно на два года ближе к концу войны, когда бы этому концу ни предстояло наступить.

- Альберт вычитал сегодня в монреальской газете, что, по мнению какого-то военного эксперта, война продлится еще пять лет, - вставила кузина София, внеся свой вклад в поддержание общего оптимизма ${ }^{2}$ (Л. М. Монтгомери, Рилла из Инглсайда; пер. М. Ю. Батищевой).

\subsection{Tożsamość autora wypowiedzi komentowanej oraz komentującej}

Wyraz metajęzykowy może dotyczyć zarówno wypowiedzi tego samego autora (1), jak i innego podmiotu komunikacyjnego (2). W pierwszym przypadku, jeśli autor nie jest tożsamy z narratorem, mamy do czynienia ze zjawiskiem autoironii:

(5) Мы направились к площади Ногина, чтобы сесть в пятнадцатый номер трамвая. На площади чернела большая толпа: давно не было трамвая. «Видно, давно нет трамвая», - тонко заметил я, а Михаил Афанасьевич [Булгаков] сказал: «Меня не то удивляет, что трамваи не ходют, меня то удивляет, что трамваи ходют» (С. Липкин, Жизнь и судьба Василия Гроссмана).

Komentarz Semiona Lipkina do własnej niezbyt odkrywczej uwagi dotyczącej przyczyny tłumów na przystanku tramwajowym (znaczenie przysłówka тонко 'таким способом, в котором проявляется проницательность, глубокое понимание чего-л., вкус, знание дела'ㄹ ${ }^{3}$ wchodzi tutaj w sprzeczność z oczywistością przedstawionej sytuacji) służy nie tylko kurtuazyjnemu deprecjonowaniu własnej osoby, ale i pogłębieniu kontrastu pomiędzy swoją nietrafną wypowiedzią a udanym wkładem w konwersację interlokutora.

Ogólnie przypadki autoironii związane z wyrazami metajęzykowymi nie są zbyt częste; większość przykładów to sytuacje, w których ocenia się cudzą wypowiedź (ta zależność statystyczna jest poniekąd nieprzypadkowa: ironię czasem opisuje się jako formę niejawnej, implicytnej agresji [Šaronov 2004], która przecież najczęściej jest skierowana na kogoś innego), por.:

2 Rosyjski przekład tutaj w pełni oddaje wszystkie istotne cechy angielskiego oryginału: „Now, Miss Oliver, dear, you know that is not a reasonable remark. You know we are just two years nearer the end, whenever the end is appointed to be."

„Albert read in a Montreal paper today that a war expert gives it as his opinion that it will last five years more," was Cousin Sophia's cheerful contribution (L. M. Montgomery, Rilla from Ingleside).

3 Znaczenia rosyjskich wyrazów tu i dalej za: [Evgen'eva 1981-1984]. 
(6) W gabinecie ministra zdrowia panował podniosły nastrój. - Jaki pan minister odważny - powiedział z zachwytem urzędnik w brązowym garniturze. - Żeby tak od razu zlikwidować centrale NFZ. Naprawde wspaniale (https://dzienniklodzki.pl/za-zdrowie-ministra/ar/789751)

\subsection{Typ sprzeczności, która zachodzi pomiędzy wyrazem metajęzykowym a kontekstem}

Warunkiem zaistnienia ironii werbalnej, jej zasadniczym elementem jest szeroko pojmowana sprzeczność czy niezgodność pomiędzy konwencjonalnym znaczeniem wyrazu czy wypowiedzi a kontekstem. Niezgodność ta pełni funkcję sygnału niezbędności ironicznej dekonstrukcji - po odczytaniu przez odbiorcę owego sygnału następuje wydobycie ukrytego sensu. Wbrew klasycznemu ujęciu ironii czy jej opisowi jako implikatury będącej konsekwencją negacji dosłownego znaczenia [Grice 1980, 107] wspomniana sprzeczność to nie zawsze radykalny kontrast - w wielu przypadkach mamy do czynienia z ledwo zauważalnym niedostosowaniem, delikatnym semantycznym, pragmatycznym lub dyskursywnym przesunięciem. Pomijając na razie kwestie ustalenia dystansu pomiędzy znaczeniem konwencjonalnym a figuratywnym, który przecież zawsze jest inny, wymienię podstawowe, jak się wydaje, typy sprzeczności dotyczące użycia jednostek metajęzykowych $\mathrm{w}$ funkcji ironicznej:

- niezgodność komponentów semantycznych w składzie jednostki metajęzykowej z formą czy treścią komentowanej wypowiedzi, przy czym może to być niezgodność stricte semantyczna, por.:

(7) Я сказал:

- Ну как?

- Чудовищно! - похвалил Борис Сергеевич (В. Драгунский, Слава Ивана Козловского).

Znaczenie nazwy aktu mowy похвалить 'высказать одобрение, похвалу кому-, чему-л.', czyli ocenić pozytywnie, wchodzi w antynomiczne relacje z oceną zawartą w wypowiedzi komentowanej (цудовищно 1 'страшно, устрашающе'4, czyli jest to określenie raczej pejoratywne). Zauważmy,

\footnotetext{
4 Słownik języka rosyjskiego w 4 tt. (red. A. P. Evgen'eva) stwierdza co prawda, iż przysłówek чудовищно funkcjonuje wyłącznie jako semantycznie motywowany przymiotnikiem чудовищныц $\mathrm{w}$ znaczeniu 2 i 3, jednak taki opis ewidentnie odbiega od tego stanu rzeczy, który ma miejsce w języku.
} 
iż reakcja bohatera rzeczywiście może być potraktowana jako wyraz zachwytu (por. чудовищно 2 'так, что это является необычным по своим размерам, величине, силе') - tę właśnie interpretację wybiera egzegetyczny narrator, który jest tutaj celem miękkiej i życzliwej ironii. Dzieli go od autora dość spory dystans. Z tym samym efektem (niegodnego zaufania narratora, o którym była już wcześniej mowa) mamy do czynienia w kolejnym przykładzie:

(8) Zacznę od krótkiej, ale treściwej naukowej prelekcji na temat nawozów sztucznych w starożytności... Już starożytni Asyryjczycy nie znali sztucznych nawozów. [...] O nawozach sztucznych nie znajdujemy też wzmianek w papirusach egipskich, których nie należy mieszać z egipskimi papierosami (J. Tuwim, Skrzynka rolnicza).

Tutaj jednak zachodzi sprzeczność, którą można określić jako niezgodność składników znaczeniowych wyrazu metajęzykowego ze stanem rzeczy $\mathrm{w}$ świecie przedstawionym, czyli w pewnym sensie faktyczną. Monolog narratora, komentowany przez niego samego, ani nie jest do końca prelekcja ('wykład popularnonaukowy na jakiś temat, przeznaczony dla szerszego kręgu słuchaczy, popularyzujący konkretną dyscyplinę wiedzy lub wybrany problem; odczyt'5), bo nie odpowiada warunkom fortunności odpowiedniego gatunku, ani nie jest krótki (w ramach artykułu nie sposób przytoczyć całego tekstu opowiadania), ani treściwy. Niezgodność faktyczną czasem niełatwo odróżnić od kolejnego typu sprzeczności.

- niezgodność komponentów semantycznych w składzie jednostki metajęzykowej z jakimś elementem czy właściwością sytuacji, w której odbywa się komunikacja, por.:

(9) Тут бабушка не выдерживала и, глядя на важных, красивых генералов с бородами и усами, которыми изнутри была оклеена крышка сундука, спрашивала у них:

- Што мне с этим дитем делать? - Генералы не отвечали. Я гладил мануфактуру (В. Астафьев, Последний поклон).

Nie ma tu sprzeczności stricte semantycznej, ale znaczenie czasownika спрашивать ('обращаться к кому-л. с вопросом, желая узнать, выяснить что-л.; осведомляться') wskazuje, że typowa sytuacja jego użycia wygląda inaczej, mianowicie typowym adresatem pytania jest człowiek,

5 Znaczenia polskich wyrazów tu i dalej za: [USJP 2004]. 
a główną intencją pytającego jest chęć zdobycia pewnej informacji. W przytoczonym przykładzie natomiast babcia nie chce się niczego dowiedzieć, jej wypowiedź pełni funkcję nie konatywną, lecz ekspresywną, a faktycznym odbiorcą tej wypowiedzi jest wnuk, narrator (a nie generałowie na obrazkach).

W kolejnym przypadku

(10) Народ был тогда неприхотлив, и на сердца слушателей действовали даже такие избитые фразы, как... «O tempora, o mores!» (Тэффи, Древняя история)

sprzeczność sytuacyjna polega na dystansie, który dzieli czas wypowiedzenia komentarza i czas powstania wypowiedzi komentowanej. Jak pisze Władimir Sannikov, „Тэффи тонко чувствует различие между временем данной речи и временем события... прилагательное избитый ориентировано на момент речи; аномально (и производит комический эффект) использование его при описании Древнего Рима, где фразы, ощущаемые нами как избитые, только возникали и таковыми отнюдь не являлись" [Sannikov 2002, 345]. Podstawą niezgodności sytuacyjnej może być niestosowność (oczywiście w odbiorze komentatora) pewnych cech wypowiedzi w opisywanej sytuacji:

(11) Hejtuje pizze hut na ul. kamiennej. Pan z zachwytem powiedział, że dostaje duzą pizze zamiast średniej, ale byla cala spalona oraz nie miała sera w brzegach tak jak zamawiałem (https://www.facebook.com/hejted. wroclaw12/photos/3820hejtuje-pizze-hut-na-ulkamiennej-pan-z-zachwytem -powiedzia\%C5\%82-\%C5\%BCe-dostaje-duz\%C4\%85-/1708029585874124/)

- niezgodność dyskursywna polegająca na użyciu jednostki metajęzykowej w nietypowych warunkach / nietypowym kontekście, por.:

(12) Сорок пять минут, опираясь своим крутым бедром о мою парту, она разорялась насчет воровства, то и дело произнося непонятное слово «плагиат» (Л. Петрушевская, Умирающая лебедь).

Napięcie ironiczne powstaje tutaj na skutek zderzenia określenia potocznego, a nawet prostackiego, zawierającego duży ładunek ekspresywny (разоряться 'выходить из себя, браниться, ругаться') oraz niestarannej konstrukcji składniowej (разоряться насчет + rzeczownik w formie dopełniacza), z opisem sytuacji oficjalnej oraz z książkowym i niezrozumiałym dla narratora słowem nлагuam.

W kontekście neutralnym natomiast efekt ironiczny może wynikać z użycia leksemów archaicznych, podniosłych, książkowych (a więc można ten typ 
sprzeczności - przynajmniej w niektórych przypadkach - nazwać również stylistycznym):

(13) - Во-первых, мы не господа, - молвил, наконец, самый юный из четверых, персикового вида (М. Булгаков, Собачье сердие).

Leksykograficzny opis czasownika молвить (semantycznie dokładnie odpowiadającego podstawowemu oznaczeniu aktu mówienia сказать) zawiera kwalifikator archaiczne. Warto zauważyć, iż leksemy tego typu we współczesnym języku rosyjskim (молвить, возопить, изречь, многоглаголание) występują wyłącznie w funkcji ironicznej. Podobnie zachowują się czasowniki typu rzec w języku polskim:

(14) Ślusarz był zaskoczony moją ciekawością, ale po pierwszym odruchu zdziwienia, które wyraziło się w spojrzeniu sponad okularów, chrząknął i rzekł:

- Bo droselklapa tandetnie zblindowana i ryksztosuje (J.Tuwim, Ślusarz).

Standardowe warunki użycia czasownika rzec wyglądają inaczej, potwierdza to kwalifikator ksiazkkowe w [USJP 2004], warto jednak odnotować, że, jak w kilku powyższych przykładach, sprzeczność tutaj nie jest radykalna; wybór czasownika świadczy m.in. o fascynacji narratora manierą wypowiedzi bohatera, która brzmi niemal jak niezrozumiałe dla profanów zaklęcie.

O ważnej roli, którą sprzeczność stylistyczna (dyskursywna) może odgrywać w tworzeniu ironii, dobitnie świadczą poniższe przykłady (oryginalny tekst Borisa Akunina i jego przekład na język polski):

(15) - Вот и отлично-с. Итак, раздался звонок - дзинь-дзинь, или треньтрень, я не знаю, как оно там у вас.

- Бряк-бряк, - поведала свидетельница. - Только меня дома не было (Б. Акунин, $\Phi M)$.

(16) - No to świetnie. A zatem rozległ się dzwonek: dzyń-dzyń albo tryń-tryń, nie wiem, jak tam u was dzwoni, dobrodziejko.

- Brzek-brzek - odpowiedziała przesłuchiwana. - Tylko że mnie nie było w domu (B. Akunin, F. M., przeł. J. Czech).

Obecna w oryginale ironia właściwie znika w tłumaczeniu, ponieważ stylistyczne charakterystyki czasowników nоведаmь oraz odpowiedzieć nie są identyczne. Potoczny wyraz dźwiękonaśladowczy бряк-бряк „kłóci się” ze wzniosłym określeniem поведать, natomiast polski czasownik jest neutralny. Można jednak w tym przypadku stwierdzić, iż dalekie echo ironii 
oryginału oddane zostało za pomocą użycia czasownika metajęzykowego, czyli określającego czynność, która posiada wartość semiotyczną, jako komentarza do potocznej onomatopei z wątpliwym statusem semiotycznym.

\section{Podsumowanie}

Warto zauważyć, że w większości zbadanych przykładów rzadko występuje tylko jeden rodzaj sprzeczności/niezgodności; zwykle różnego typu napięcia współdziałają ze sobą, dlatego tym bardziej każde z nich powinno zostać wyodrębnione i dokładnie opisane.

Podsumowując, podkreślę, iż właśnie przykłady o opisanej w artykule strukturze $\mathrm{w}$ sposób na ile to możliwe jawny przedstawiają te składniki wypowiedzi ironicznej, pomiędzy którymi zachodzi sprzeczność, a więc umożliwiają uściślenie typu oraz stopnia tej sprzeczności oraz weryfikację wniosków.

\section{Literatura}

Attardo S., 2002, Humor and Irony in Interaction: From Mode Adoption to Failure of Detection, [w:] Say not to Say: New Perspectives on Miscommunication, L. Anolli, R. Ciceri, G. Riva (red.), Amsterdam-Washington, s. 166-185.

Charciarek A., 2010, Polskie wyrażenia metatekstowe o funkcji fatycznej i ich odpowiedniki czeskie i rosyjskie, Katowice.

Gray J.C., 1960, Irony: A Practical Definition, „College English”, vol. 21, nr 4, s. $220-222$.

Grice P., 1980, Logika a konwersacja, [w:] Jezyk w świetle nauki, B. Stanosz (red.), Warszawa, s. 91-114.

Hühn P., Pier J., Schmid W., Schönert J. (red.), 2009, Handbook of narratology, Berlin, New York.

Jakobson R., 1960, Poetyka w świetle językoznawstwa, „Pamiętnik Literacki”, nr 2, s. $431-473$.

Kreuz R.G., Link K.E., 2002, Asymmetries in the Use of Verbal Irony, „Journal of Language and Social Psychology", vol. 21, nr 2, s. 127-143.

Lucy J.A., 1999, Reflexivity, „Journal of Linguistic Anthropology”, vol. 9, nr 1/2, s. $212-215$.

Ożóg K., 1990, Leksykon metatekstowy wspótczesnej polszczyzny mówionej. Wybrane zagadnienia, Kraków.

Piekarczyk D., 2012, Problem metajezyka i metatekstu, [w:] Stowa, style, metody, H. Pelcowa, M. Wojtak (red.), Lublin, s. 217-234. 
Starodworskaja E., 2020, Metajęzykowe oblicze ironii, „Studia Rossica Posnaniensia" nr XLV/1, s. 205-214.

Uniwersalny słownik języka polskiego, 2004, Wydawnictwo Naukowe PWN, Warszawa.

Wierzbicka A., 1971, Metatekst w tekście, [w:] O spójności tekstu, M.R. Mayenowa (red.), Wrocław, s. 105-121.

Padučeva E.V., 1996, Semantičeskie issledovaniâ (Semantika vremeni $i$ vida $v$ russkom âzyke; Semantika narrativa), Moskva. [Падучева E.B., 1996, Семантические исследования (Семантика времени и вида в русском языке; Семантика нарратива), Москва.]

Sannikov V.Z., 2002, Russkij âzyk v zerkale âzykovoj igry, Moskva. [Санников B.3., 2002, Русский язык в зеркале языковой игрь, Москва.]

Slovar' russkogo âzyka: V 4-h t., 1981-1984, A.P. Evgen'eva (red.), Moskva. [Cлoварь русского языка: В 4-х т., 1981-1984, А.П. Евгеньева (ред.), Москва.]

Šaronov I.A., 2004, Priemy rečevoj agressii: nasmeška iironiâ, [w:] Agressiâ v âzyke i reči, Moskva, s. 38-52. [Шаронов И.А, 2004, Приемь речевой агрессии: насмешка и ирония, [w:] Агрессия в языке и речи, Москва, с. 38-52.]

\section{TOWARDS A PRELIMINARY TYPOLOGY OF AN IRONICAL METALINGUISTIC EXPRESSIONS IN RUSSIAN AND POLISH LANGUAGES}

ABSTRACT

The paper is an attempt to determine the features of an ironical metalinguistic (reflexive) expressions that could be used as a criteria for these expressions typology and to present the draft of such typology. Relevant features of units studied here are provided by results of semantic, pragmatic and discourse analysis of some examples. It is shown that basic criteria include the identity of reflexive comment sender, the relations between communicative agents and the type of contradiction between the metalinguistic expression and the context (generally the utterance commented by an ironist).

Key words: verbal irony, Polish language, Russian language, metalinguistic expressions 